Pacific Journal of Mathematic 


\section{REMARK ON THE PRECEDING PAPER ALGEBRAIC EQUATIONS SATISFIED BY ROOTS OF NATURAL NUMBERS}

E. G. Straus and O. Taussky

In the preceding paper [1] it was shown that the polynomials in question are factors of $\Phi_{h}\left(x^{k} / n\right)$ where $\Phi_{n}$ is the cyclotomic polynomial of order $h$ and $k, n$ are positive integers. The case $k=2$ was settled in [1, Lemma 2]. It will now be shown that this is essentially the only nontrivial case. For a different treatment of a somewhat related question see K. T. Vahlen [2].

First let us remark that we can exclude the case $n=m^{d}$ where $d / k$, $d>1$; since we may then set $y=x^{k / a} / m$ so that $\Phi_{h}\left(y^{d}\right)$ is either reducible with cyclotomic factors or equal to $\Phi_{h d}(y)$. We shall refer to $n$ and $\Phi_{h}\left(x^{k} / n\right)$ which satisfy the above exclusion as simplified.

THeOREM. The simplified polynomial $\Phi_{h}\left(x^{k} / n\right)$ is irreducible for all odd $k$. For $k=2 l$ the polynomial is reducible if and only if $\Phi_{h}\left(x^{2} / n\right)$ is reducible. In that case we have

$$
\Phi_{l}\left(x^{k} / n\right)=g\left(x^{l}\right) g\left(-x^{l}\right),
$$

where the polynomials on the right are irreducible.

The proof is based on the following lemma.

Lemma. If $k>2$ and $n^{1 / k}$ is simplified then $n^{1 / k}$ is not contained in a cyclotomic field.

Proof. The Galois group of a cyclotomic field $R(\zeta)$ is Abelian and hence all subfields of $R(\zeta)$ are normal. The field $R\left(n^{1 / k}\right)$ is, however, not a normal field for $k>2$.

We can now prove the Theorem. Let $\zeta_{h}$ be a primitive $h$ th root of unity. A zero $\omega$ of a simplified $\Phi_{h}\left(x^{k} / n\right)$ is a zero of

$$
x^{k}-n \zeta_{h}
$$

and hence $R(\omega)$ is an algebraic extension of $R\left(\zeta_{h}\right)$. If the degree of $R(\omega)$ over $R\left(\zeta_{h}\right)$ were $k$ then its degree over $R$ would be $k \varphi(h)$. Hence $\Phi_{h}\left(x^{k} / n\right)$ is reducible if and only if (2) is reducible over $R\left(\zeta_{h}\right)$. Say

$$
x^{k}-n \zeta_{h}=F(x) G(x) \quad F, G \in R\left(\zeta_{h}\right)[x] .
$$

Since all the roots of (2) are of the form $n^{1 / k} \zeta_{k h}^{s}$ we have

Received July 11, 1955. 


$$
F(0)=n^{l / k} \zeta \in R\left(\zeta_{h}\right) \quad l=\operatorname{deg} F
$$

where $\zeta$ is a root of unity. In other words

$$
n^{l / k} \in R\left(\zeta_{h}, \zeta\right)=R\left(\zeta^{\prime}\right)
$$

where $\zeta^{\prime}$ is a root of unity.

According to the lemma (4) is impossible if the reduced fraction $1 / k$ has denominator $>2$. For $k$ odd this means $l=0$ or $k$ and $\Phi_{h}\left(x^{k} / n\right)$ irreducible. For $k$ even and $0<l<k$ we can have only $l=k / 2$. In this case

$$
F(0)= \pm n^{1 / 2} \zeta_{h k}^{s}, \quad G(0)= \pm n^{1 / 2} \zeta_{h k}^{t} ;
$$

and since both $F(0) G(0)$ and $F(0) / G(0)$ are in $R\left(\zeta_{h}\right)$ we obtain

$$
s+t \equiv s-t \equiv 0(\bmod k) .
$$

Hence $s \equiv t \equiv 0(\bmod l)$ so that

$$
F(0)=\sqrt{n \zeta_{h}^{u}} \in R\left(\zeta_{h}\right) .
$$

But we noted in [1, Lemma 1] that (5) is necessary and sufficient for the reducibility of $\Phi_{h}\left(x^{2} / n\right)$. Thus we have

$$
\begin{aligned}
& \Phi_{h}\left(x^{2} / n\right)=g(x) g(-x) \text { and therefore } \\
& \Phi_{h}\left(x^{k} / n\right)=g\left(x^{l}\right) g\left(-x^{l}\right)
\end{aligned}
$$

as the complete factorization of $\Phi_{h}\left(x^{k} / n\right)$ over $R[x]$.

\section{REFERENCES}

1. A. J. Hoffman, M. Newman, E. G. Straus, O. Taussky, The number of absolute points of a correlation, Pacific J. Math., 6 (1956).

2. K. T. Vahlen, Über reductible Binome, Acta. Math., 19 (1895).

UNIVERSITY OF CALIFORNIA, LOS ANGELES

NATIONAL BUREAU OF STANDARDS 


\section{PACIFIC JOURNAL OF MATHEMATICS}

\section{EDITORS}

H. L. Royden

Stanford University

Stanford, California

E. HewitT

University of Washington

Seattle 5 , Washington
R. P. Dilworth

California Institute of Technology Pasadena 4, California

E. G. Straus

University of California

Los Angeles 24, California

\section{ASSOCIATE EDITORS}

E. F. BECKENBACH

C. E. BURGESS

H. BUSEMANN

H. FEDERER

\author{
M. HALL \\ P. R. HALMOS \\ V. GANAPATHY IYER \\ R. D. JAMES
}

M. S. KNEBELMAN

I. NIVEN

T. G. OSTROM

M. M. SCHIFFER
J. J. STOKER

G. SZEKERES

F. WOLF

K. YOSIDA

\section{SUPPORTING INSTITUTIONS}

UNIVERSITY OF BRITISH COLUMBIA

CALIFORNIA INSTITUTE OF TECHNOLOGY

UNIVERSITY OF CALIFORNIA

MONTANA STATE UNIVERSITY

UNIVERSITY OF NEVADA

OREGON STATE COLLEGE

UNIVERSITY OF OREGON

UNIVERSITY OF SOUTHERN CALIFORNIA
STANFORD UNIVERSITY

UNIVERSITY OF UTAH

WASHINGTON STATE COLLEGE

UNIVERSITY OF WASHINGTON

AMERICAN MATHEMATICAL SOCIETY CALIFORNIA RESEARCH CORPORATION HUGHES AIRCRAFT COMPANY 


\section{Pacific Journal of Mathematics}

\section{Vol. 6, No. $1 \quad$ November, 1956}

David Blackwell, An analog of the minimax theorem for vector payoffs..... 1

L. W. Cohen, A non-archimedian measure in the space of real

sequences ..................................... 9

George Bernard Dantzig, Constructive proof of the Min-Max theorem ..... 25

Jim Douglas, On the numerical integration of quasilinear parabolic

differential equations ............................... 35

James Michael Gardner Fell, A note on abstract measure ............. 43

Isidore Isaac Hirschman, Jr., A note on orthogonal systems . . . . . . . . . . 47

Frank Harary, On the number of dissimilar line-subgraphs of a given

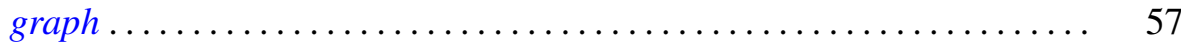

Newton Seymour Hawley, Complex bundles with Abelian group......... 65

Alan Jerome Hoffman, Morris Newman, Ernst Gabor Straus and Olga

Taussky, On the number of absolute points of a correlation ...........

Ernst Gabor Straus and Olga Taussky, Remark on the preceding paper.

Algebraic equations satisfied by roots of natural numbers . . ........ 97

Ralph D. James, Summable trigonometric series ................. 99

Gerald R. Mac Lane, Limits of rational functions . . . . . . . . . . . . . . . 111

F. Oberhettinger, Note on the Lerch zeta function ................. 117

Gerald C. Preston, On locally compact totally disconnected Abelian groups and their character groups ........................... 121

Vikramaditya Singh and W. J. Thron, On the number of singular points, located on the unit circle, of certain functions represented by

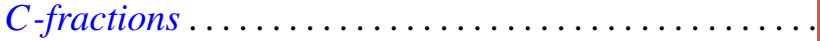

Sherman K. Stein, The symmetry function in a convex body ... 145 Edwin Weiss, Boundedness in topological rings.............

Albert Leon Whiteman, A sum connected with the series for the partition

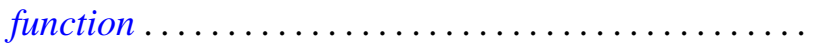

Alfred B. Willcox, Some structure theorems for a class of Banach algebras.

Joseph Lawrence Zemmer, Some remarks on p-rings and their Boolean geometry... 